\title{
Development and Optimization of Jaggery Based Cold Extruded Products
}

\author{
B. Pravallika ${ }^{*}$, S. Patel ${ }^{1}$, P.V.K. Jagannadha Rao $^{2}$ and P. Sreedevi ${ }^{3}$ \\ ${ }^{I}$ Department of APFE, Faculty of Agricultural Engineering, IGKV, Raipur, India \\ ${ }^{2}$ College of Agricultural Engineering, Madakasira, (A.P.), India \\ ${ }^{3}$ AICRP on Post-Harvest Engineering and Technology, RARS, Anakapalle (A.P.), India
}

*Corresponding author

\begin{tabular}{|l|}
\hline K e y w o r d s \\
$\begin{array}{l}\text { Jaggery, Cold extrusion, } \\
\text { Response surface } \\
\text { methodology, Hardness, } \\
\text { Bulk density }\end{array}$ \\
\hline Article Info \\
\hline $\begin{array}{l}\text { Accepted: } \\
\text { 20 August } 2018 \\
\text { Available Online: } \\
\text { 10 September } 2018\end{array}$ \\
\hline
\end{tabular}

\section{Introduction}

Jaggery is the sugarcane based traditional Indian sweetener. Jaggery is a traditional unrefined non-centrifugal sugar consumed in Asia, Africa, Latin America and the Caribbean. It is a concentrated product of date, cane juice, or palm sap without separation of the molasses and crystals, and can vary from golden brown to dark brown in colour and is considered as a special because of its inherent taste and aroma due to high molasses content. Containing all the minerals and vitamins present in sugarcane juice, it is known as healthiest sugar in the world. India is the largest producer and consumer of jaggery. Out of total world production, more than $70 \%$ is produced in India. It is consumed in almost all 
sections of the society as a sweetener, and as a source of energy. It is also used in animal feed mixtures (Nath et al., 2015). In cement industries and coalmines jaggery is supplied to the workers in order to protect them from dust allergies (Shrivastav et al., 2016).

Jaggery, a product of sugarcane, is rich in important minerals (viz., calcium-40-100 mg, magnesium-70-90 mg, potassium-1056 mg, phosphorus-20-90 mg, sodium-19-30 mg, iron-10-13 mg, manganese-0.2-0.5 mg, zinc0.2- $0.4 \mathrm{mg}$, copper-0.1-0.9 mg, and chloride$5.3 \mathrm{mg}$ per $100 \mathrm{~g}$ of jaggery), vitamins (viz., vitamin A-3.8 $\mathrm{mg}$, vitamin B1-0.01 $\mathrm{mg}$, vitamin B2-0.06 $\mathrm{mg}$, vitamin B5-0.01 $\mathrm{mg}$, vitamin B6-0.01 $\mathrm{mg}$, vitamin C-7.00 mg, vitamin D2-6.50 mg, vitamin E-111.30 mg, vitamin PP-7.00 mg), and protein-280 mg per $100 \mathrm{~g}$ of jaggery, which can be made available to the masses to mitigate the problems of mal nutrition and under nutrition (Singh et al., 2011).

Value addition to solid jaggery by inclusion of nutritive substances through puffed rice, gram, sesame and various kinds of nuts (cashew, almond), vitamins, iron, and taste enhancers like chocolate powder will increase demand for this kind of jaggery. Almost all food products that can be prepared with refined sugar can also be prepared with jaggery. Products like cakes, sweets, pooranpoli, chikkis and candies are mostly prevalent (Jaggery Research in India, 2015). The nutritive value and palatability can be enhanced by preparing different kinds of jaggery with the addition of puffed rice, gram and groundnut, mixing with wheat flour and mixing with gram flour. The jaggery with $10 \%$ cocoa powder yielded a product (chocolate) which was very much acceptable as a substitute for chocolate. Value added jaggery will be a cheap source of nutrition to the poor and malnourished (Prashant et al., 2013). Padma et al., (2015) developed a ready-to-eat nutritious ladoo mix by blending the flour of sprouted, roasted grains like wheat, ragi, jowar, bajra, green gram and horse gram with jaggery in an optimized proportion of 1:1:1.6. Other ingredients like powdered cardamom and sesame were added in small amounts to enhance the flavour. Khulve et al., (2015) prepared jaggery based energy bar using jaggery powder, skimmed milk powder, and $40 \%$ of total quantity of butter.

Noodles of different combinations are prepared such as noodles exclusively made of finger millet, finger millet and wheat in the ratio of 1:1 and finger millet blended with wheat and soy flour in the ratio of $5: 4: 1$. Generally, in the preparation of noodles, wheat flour is invariably used as an important member of blend because the presence of wheat gluten has an added advantage which not only helps in easy extrusion but also gives a smooth and fissure free texture to the noodles (Veenu et al., 2012). Devraju et al., (2003) developed pasta with Finger millet flour $(50 \%)$, refined wheat flour (40\%), defatted soy/whey protein concentrate $(10 \%)$ and extruded using both cold $\left(30^{\circ} \mathrm{C}\right)$ and hot water $\left(75^{\circ} \mathrm{C}\right)$. Sanjarambam et al., (2015) developed millet fortified cold extruded pasta products and to study the quality attributes of the developed products. Khan et al., (2012) developed a jaggery based extruded snack using blends of soy-flour, wheat-flour and jaggery. Shanthi et al., (2005) studied the effect of incorporation of finger millet in pasta products. Archana (2001) also reported that pasta prepared from pearl millet and fenugreeks (80:20) were found to be very much acceptable. Ranganna et al., (2012) used a sophisticated Brabender Single Screw Extruder to develop small millets based extruded pasta by blending cassava flour.

Nutritionally balanced extruded snacks food products using jaggery as a sweetener is not yet been developed. The incorporation of 
jaggery into the blend of soya flour and wheat flour increases the taste and overall acceptability. Extruded snacks prepared from wheat-soy flour and jaggery can fulfill the requirement of all nutrients up to some extent and may provide a good neutraceutical diet (Khan et al., 2012). Making such value added multi grain flour and jaggery based extruded products may enhance protein and energy intake of the vulnerable group at comparatively economic cost.

\section{Materials and Methods}

\section{Experimental site}

The experiment was carried out at AICRP on PHET, Regional Agricultural Research Station.

\section{Raw materials}

The raw materials used for the development of jaggery based cold extruded products were multigrain flour (wheat flour, ragi flour and corn flour), maida and jaggery powder.

\section{Material source}

\section{Multi grain flour}

Multi grain flour was prepared by selecting, milling and mixing of flour of different grains. In present study, the multi grain flour was prepared by using three types of grains namely ragi, wheat and corn. The selection of ingredients for making multi grain flour was based on the review and the local availability of ingredients to be mixed. Readily available milled wheat flour, ragi flour and corn seeds were purchased from the local market. The corn seeds were made into corn flour by using domestic grain burr mill locally available at Anakapalle. The selected three ingredients were mixed thoroughly and uniformly to make multi grain flour. The composition of multi grain flour was optimized by conducting preliminary experiments with different ratios of ingredient flours.

\section{Maida flour}

Maida flour was purchased from the local market at Anakapalle. It is used as a binding agent that helps to produce smooth finished cold extruded products.

\section{Jaggery powder}

Fresh jaggery powder was made from sugarcane juice at jaggery manufacturing unit situated at RARS, Anakapalle

\section{Equipment}

The laboratory model Pasta Machine (make: La Monferrina, Italy; model: P12) was used for the experiment and was basically a medium, compact cold extruder (Plate 3.1). The unit was basically a single screw extruder with a short stainless steel screw of uniform pitch powered by a $3 \mathrm{hp}$ electrical motor through a speed reduction system.

\section{Preliminary experiments}

Preliminary studies were conducted on the basis of review conducted on development of various extruded products to decide the suitable composition of multi grain flour to prepare jaggery based cold extruded products. In view of results obtained from preliminary experiments the variable and actual levels were decided.

\section{Experimental design}

The multi grain flour having composition of $50 \%$ of wheat flour, $30 \%$ of corn flour and $20 \%$ of ragi flour was found to be acceptable to prepare jaggery based cold extruded products after conducting preliminary 
experiments. The effect of three independent variables on the response was studied using a three-level, four-factor Central Composite Rotatable Design (CCRD) of Response Surface Methodology (RSM) (Ferreira et al., 2009). The four independent variables were multigrain flour $\left(X_{1}\right)$, maida flour $\left(X_{2}\right)$, jaggery powder $\left(\mathrm{X}_{3}\right)$ and water $\left(\mathrm{X}_{4}\right)$ and each variable was set at three levels. The range and levels of variables investigated are given in Table 2.

A total of 30 experiments were designed with sixteen tests of factorial points (three levels for each factor), eight axial points (two for each variable) and six repetitions of central points. Regression analysis was performed for the experiment data and fitted to the empirical second order polynomial model, as shown in the following equation:

$Y=\beta_{0}+\beta_{1} X_{1}+\beta_{2} X_{2}+\beta_{3} X_{3}+\beta_{3} X_{4}+\beta_{11} X_{1}^{2}+$ $\beta_{22} X_{2}{ }^{2}+\beta_{33} X_{3}{ }^{2}+\beta_{44} X_{4}{ }^{2}$

$\beta_{12} X_{1} X_{2}+\beta_{13} X_{1} X_{3}+\beta_{23} X_{2} X_{3}+\beta_{24} X_{2} X_{4}+$ $\beta_{14} X_{1} X_{4}+\beta_{34} X_{3} X_{4}$

\section{Development of jaggery based cold extruded products}

The jaggery based cold extruded products were manufactured by the following systematic procedure advocated by the single screw extruder machine manufacturer. All the ingredients (multi grain flour, maida flour and jaggery powder) were mixed for $5 \mathrm{~min}$ and then kneaded for about $45 \mathrm{~min}$ after adding optimum quantity of water. The quantity of water was decided based on manufacturer recommendations and the preliminary experiments. When the dough characteristic was optimum, it was extruded using appropriate dies or plates (in all available shapes - shanku, ribbed tube, twisted ribbons). The cutter was operated manually according to the discharge of product and its speed could ranges from 3 to $12 \mathrm{rpm}$ depending upon the shape of the final product. The extruded products were cooled to some extent by the fan provided at the bottom and were collected in trays. The collected extruded products were dried in a tray dryer for storage.

Physical parameters of jaggery based cold extruded products

\section{Bulk density}

Bulk density is the mass per unit bulk volume of the material where the volume includes the volume of voids. It was worked out by tapping method. The extrudates were filled in a measuring cylinder of capacity $100 \mathrm{ml}$ and tapped. The extrudates were allowed to settle thoroughly inside the cylinder. The tapping of the cylinder was stopped when no more settling was observed. It was weighed and the mass of $100 \mathrm{ml}$ sample was recorded. The bulk density was worked out using following formula:

Bulk density, $\mathrm{g} / \mathrm{cc}=\frac{\text { Weight of sample }}{\text { Volume of sample }}$

\section{Hardness}

The hardness of jaggery based cold extruded products was determined by using TA. XT. PLUS texture analyzer A cylindrical probe P25 was used for compression of the samples. Each sample was triplicated and the average reading was noted.

\section{TA settings}

Mode: Measure Force in Compression

Pre Text speed: $10 \mathrm{~mm} / \mathrm{s}$

Test speed: $1 \mathrm{~mm} / \mathrm{s}$

Post Test speed: $10 \mathrm{~mm} / \mathrm{s}$

Distance (compression): $3 \mathrm{~mm}$

Data Acquisition Rate: 200 pps 


\section{Results and Discussions}

\section{Bulk density}

The bulk density of jaggery based cold extruded products was found to be varied from 0.31 to $0.47 \mathrm{~g} / \mathrm{cc}$. The lowest bulk density was found for R29 (MGF-400 g, MF-65 g, JP- 200 $\mathrm{g}$, Water-72.5 ml) and the highest run was found for R25 (MGF-350 g, MF-75 g, JP- 225 $\mathrm{g}$, Water-80 ml). The bulk density values for all the samples was given in Appendix-A. The bulk density of jaggery based extruded snack from soy-wheat flour by using hand operated extruder was ranged between 1.027 to 1.496 $\mathrm{g} / \mathrm{cc}$ (Khan et al., 2012). The bulk density of cold extruded snacks produced from blends of breadfruit, cashew nut, and defatted coconut was ranged from 0.32 to $0.51 \mathrm{~g} / \mathrm{cm}^{3}$ (Gabriel et al., 2014).

\section{Hardness}

The hardness of the jaggery based cold extruded products was ranged from 3871.02 to $14534.50 \mathrm{~N}$ (Table 6). The minimum hardness was found for R14 (MGF-300 g, MF-85 g, JP$200 \mathrm{~g}$, Water-72.5 ml) and the maximum hardness was found for R5 (MGF-450 g, MF$75 \mathrm{~g}$, JP- $175 \mathrm{~g}$, Water-65 ml). The samples having optimum hardness were found to be acceptable. The hardness values for all the samples were given in Table 1 .

\section{Optimization of Jaggery based cold extruded products}

\section{Fitting the model}

Three level factorial method was used to optimize the process conditions for the application of jaggery based cold extruded products. In order to study the effects of the four independent variables viz, A Multi grain flour (MGF, 350-450 g), B Maida flour (75-95 g), C Jaggery powder (JP, 175-225 g) and D
Water (65- $80 \mathrm{ml})$, Central Composite Rotatable Design of Response methodology was applied. ANOVA was used to evaluate the significance of the coefficients of the models. For any of the terms in the model, a large regression coefficient and a small pvalue would indicate a more significant effect on the respective response variables (Quanhong and Caili, 2005). Analysis of variance (ANOVA) showed that the resultant second order polynomial model adequately represented the experimental data with the coefficient of multiple determinations $\left(\mathrm{R}^{2}\right)$ and adjusted $\mathrm{R}^{2}$ for the equilibrium moisture content (EMC), being 0. 9788 and 0.9785, respectively (Table 2).

The final equation for bulk density is given as

Bulk density $=+3.53456-1.24433 \mathrm{E}-003 *$ MGF +3.97996E-003* MF -6.43777E-003* JP $-0.071042 *$ Water $-1.49863 \mathrm{E}-005 *$ MGF $* \mathrm{MF}-9.00546 \mathrm{E}-006 * \mathrm{MGF} * \mathrm{JP}+1.12933 \mathrm{E}-$ $006 *$ MGF * Water $-3.80191 \mathrm{E}-005 * \mathrm{MF} * \mathrm{JP}$ $+1.15619 \mathrm{E}-004 * \mathrm{MF} *$ Water $+4.48634 \mathrm{E}-005$ * JP * Water +5.33015E-006 * MGF2 $+1.65870 \mathrm{E}-005^{*}$ MF2 +2.59627E-005* JP2 $+3.62548 \mathrm{E}-004 *$ Water2 (4.1)

The final equation for hardness is given as

Hardness $=+42794.58795+345.62511 *$ MGF $+825.42218 *$ MF $-381.88523 *$ JP $2465.72921 *$ Water $-0.60842 * \mathrm{MGF} * \mathrm{MF}$ $0.019057 *$ MGF* JP $-0.76126 *$ MGF *Water $-1.05267 * \mathrm{MF} * \mathrm{JP}-1.51066 * \mathrm{MF} *$ Water $+4.98910 * \mathrm{JP} *$ Water $-0.27990 * \mathrm{MGF} 2-$ $1.33484 * \mathrm{MF} 2+0.26017 * \mathrm{JP} 2+10.68963 *$ Water2 (4.2)

\section{Analysis of variance for selected models}

The Model F-value of 0.78 implies the model was not significant. There was only a $67.60 \%$ chance that an F-value this large could occur due to noise (Table 3-5). 
Table.1 Experimental setup for the production of jaggery based cold extruded products

\begin{tabular}{|c|c|c|c|c|c|c|}
\hline Factor & Name & Units & Type & Minimum & Maximum & Levels \\
\hline 1 & $\begin{array}{l}\text { Multi grain } \\
\text { flour }\end{array}$ & gm & Numeric & 350 & 450 & 3 \\
\hline 2 & Maida flour & gm & Numeric & 75 & 95 & 3 \\
\hline 3 & $\begin{array}{l}\text { Jaggery } \\
\text { powder }\end{array}$ & gm & Numeric & 175 & 225 & 3 \\
\hline 4 & Water & $\mathrm{ml}$ & Numeric & 65 & 80 & 3 \\
\hline
\end{tabular}

Table.2 Hardness of jaggery based cold extruded products

\begin{tabular}{|c|c|c|c|}
\hline Sample & $\begin{array}{c}\text { Hardness } \\
\text { N }\end{array}$ & Sample & $\begin{array}{c}\text { Hardness } \\
\text { N }\end{array}$ \\
\hline $\mathbf{1}$ & 14283.57 & 16 & 14356.86 \\
\hline $\mathbf{2}$ & 7592.67 & 17 & 9536.31 \\
\hline $\mathbf{3}$ & 7796.67 & 18 & - \\
\hline $\mathbf{4}$ & 5125.28 & 19 & 5387.21 \\
\hline $\mathbf{5}$ & 14534.50 & 20 & - \\
\hline $\mathbf{6}$ & 9508.86 & 21 & 5752.96 \\
\hline $\mathbf{7}$ & 6272.59 & 22 & - \\
\hline $\mathbf{8}$ & - & 23 & 9293.19 \\
\hline $\mathbf{9}$ & 8866.88 & 24 & 8982.04 \\
\hline $\mathbf{1 0}$ & - & 25 & 7470.82 \\
\hline $\mathbf{1 1}$ & 9291.48 & 26 & - \\
\hline $\mathbf{1 2}$ & - & 27 & 9548.32 \\
\hline $\mathbf{1 3}$ & - & 28 & 7464.37 \\
\hline $\mathbf{1 4}$ & 3871.02 & 29 & 8197.09 \\
\hline $\mathbf{1 5}$ & 6177.84 & 30 & 11720.92 \\
\hline
\end{tabular}

Table.3 Analysis of variance (ANOVA)

\begin{tabular}{|l|l|l|}
\hline S. No & & EMC $(\%$ dlb. $)$ \\
\hline 1 & Std. Dev. & 0.12 \\
\hline 2 & Mean & 13.87 \\
\hline 3 & C.V. $\%$ & 2.05 \\
\hline 4 & R-Squared & 0.9788 \\
\hline 5 & Adj R-Squared & 0.9785 \\
\hline
\end{tabular}


Table.4 ANOVA showing the coefficient quadratic model for bulk density

\begin{tabular}{|c|c|c|c|c|c|}
\hline Source & $\begin{array}{c}\text { Sum of } \\
\text { Squares }\end{array}$ & Df & $\begin{array}{c}\text { Mean } \\
\text { Square }\end{array}$ & $\begin{array}{c}\text { F } \\
\text { Value }\end{array}$ & $\begin{array}{c}\text { p-value } \\
\text { Prob }>\text { F }\end{array}$ \\
\hline Model & 0.023595 & 14 & 0.001685 & 0.775968 & 0.6760 \\
\hline A-MGF & $3.61 E-05$ & 1 & $3.61 \mathrm{E}-05$ & 0.016608 & 0.9011 \\
\hline B-MF & 0.004769 & 1 & 0.004769 & 2.195854 & 0.1819 \\
\hline C-JP & 0.00106 & 1 & 0.00106 & 0.488278 & 0.5072 \\
\hline D-Water & 0.000433 & 1 & 0.000433 & 0.19938 & 0.6687 \\
\hline AB & 0.000645 & 1 & 0.000645 & 0.296839 & 0.6028 \\
\hline AC & 0.001455 & 1 & 0.001455 & 0.669918 & 0.4400 \\
\hline AD & $2.06 E-06$ & 1 & $2.06 \mathrm{E}-06$ & 0.000948 & 0.9763 \\
\hline BC & 0.001127 & 1 & 0.001127 & 0.51881 & 0.4947 \\
\hline BD & 0.000938 & 1 & 0.000938 & 0.431825 & 0.5321 \\
\hline CD & 0.000883 & 1 & 0.000883 & 0.40636 & 0.5441 \\
\hline $\mathbf{A}^{\mathbf{2}}$ & 0.002984 & 1 & 0.002984 & 1.373773 & 0.2795 \\
\hline B $^{2}$ & $4.62 \mathrm{E}-05$ & 1 & $4.62 \mathrm{E}-05$ & 0.021286 & 0.8881 \\
\hline $\mathbf{C}^{2}$ & 0.002911 & 1 & 0.002911 & 1.340447 & 0.2849 \\
\hline $\mathbf{D}^{\mathbf{2}}$ & 0.004598 & 1 & 0.004598 & 2.117227 & 0.1890 \\
\hline Residual & 0.015203 & 7 & 0.002172 & & \\
\hline Lack of Fit & 0.013781 & 6 & 0.002297 & 1.614976 & 0.5387 \\
\hline Pure Error & 0.001422 & 1 & 0.001422 & & \\
\hline Cor Total & 0.038798 & 21 & & & \\
\hline
\end{tabular}

Table.5 ANOVA showing the coefficient quadratic model for hardness

\begin{tabular}{|c|c|c|c|c|c|}
\hline Source & $\begin{array}{c}\text { Sum of } \\
\text { Squares }\end{array}$ & Df & $\begin{array}{c}\text { Mean } \\
\text { Square }\end{array}$ & $\begin{array}{c}\text { F } \\
\text { Value }\end{array}$ & $\begin{array}{c}\text { p-value } \\
\text { Prob > F }\end{array}$ \\
\hline Model & $1.51 E+08$ & 14 & 10765566 & 2.366385 & 0.1276 \\
\hline A-MGF & 6095617 & 1 & 6095617 & 1.339881 & 0.2850 \\
\hline B-MF & 2338726 & 1 & 2338726 & 0.514077 & 0.4966 \\
\hline C-JP & 1380105 & 1 & 1380105 & 0.303362 & 0.5989 \\
\hline D-Water & 87657202 & 1 & 87657202 & 19.26797 & 0.0032 \\
\hline AB & 1062634 & 1 & 1062634 & 0.233578 & 0.6436 \\
\hline AC & 6515.759 & 1 & 6515.759 & 0.001432 & 0.9709 \\
\hline AD & 935746.2 & 1 & 935746.2 & 0.205687 & 0.6639 \\
\hline BC & 863838.9 & 1 & 863838.9 & 0.189881 & 0.6761 \\
\hline BD & 160111.4 & 1 & 160111.4 & 0.035194 & 0.8565 \\
\hline CD & 10914713 & 1 & 10914713 & 2.399168 & 0.1653 \\
\hline $\mathbf{A}^{2}$ & 8227652 & 1 & 8227652 & 1.808524 & 0.2206 \\
\hline B $^{2}$ & 299402.7 & 1 & 299402.7 & 0.065812 & 0.8049 \\
\hline C $^{2}$ & 292361.7 & 1 & 292361.7 & 0.064264 & 0.8072 \\
\hline D $^{2}$ & 3997633 & 1 & 3997633 & 0.878722 & 0.3798 \\
\hline Residual & 31845612 & 7 & 4549373 & & \\
\hline Lack of Fit & 31755467 & 6 & 5292578 & 58.71175 & 0.0996 \\
\hline Pure Error & 90145.12 & 1 & 90145.12 & & \\
\hline Cor Total & $1.83 E+08$ & 21 & & & \\
\hline
\end{tabular}


Table.6 Optimization criteria for different factors and responses

\begin{tabular}{|l|c|c|c|c|c|c|}
\hline $\begin{array}{c}\text { Constraints } \\
\text { name }\end{array}$ & Goal & $\begin{array}{c}\text { Lower } \\
\text { limit }\end{array}$ & $\begin{array}{c}\text { Upper } \\
\text { limit }\end{array}$ & $\begin{array}{c}\text { Lower } \\
\text { weight }\end{array}$ & $\begin{array}{c}\text { Upper } \\
\text { weight }\end{array}$ & Importance \\
\hline MGF & in range & 350 & 405 & 1 & 1 & 3 \\
\hline MF & equal to & 75 & 95 & 1 & 1 & 3 \\
\hline JP & Target & 175 & 225 & 1 & 1 & 3 \\
\hline Water & equal to & 65 & 80 & 1 & 1 & 3 \\
\hline Bulk Density & Maximize & 0.31 & 0.47 & 1 & 1 & 3 \\
\hline Hardness & Minimize & 3871.03 & 14534.5 & 1 & 1 & 3 \\
\hline
\end{tabular}

Fig.1 Single screw extruder

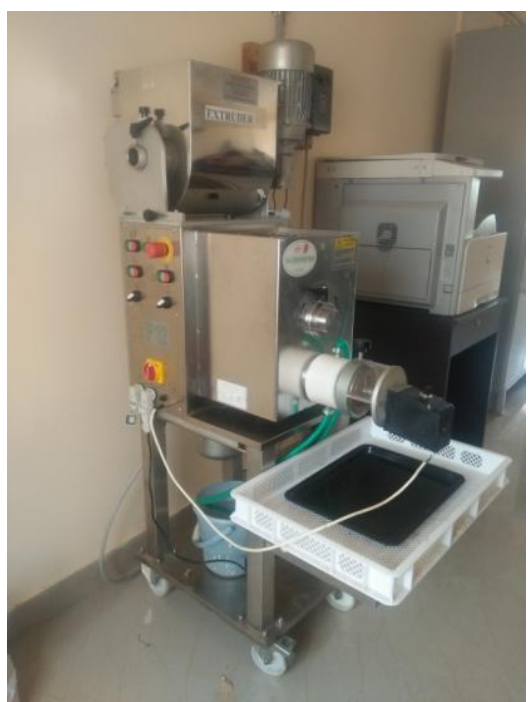

Fig.1 3D surface plot for the effect of MF and MGF on bulk density of jaggery based cold extruded products

Design-Expert® Softw are

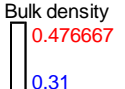

$\mathrm{X} 1=\mathrm{A}: \mathrm{MGF}$

$\mathrm{X} 2=\mathrm{B}: \mathrm{MF}$

Actual Factors

C: $J P=200.00$

D: WATER $=72.50$

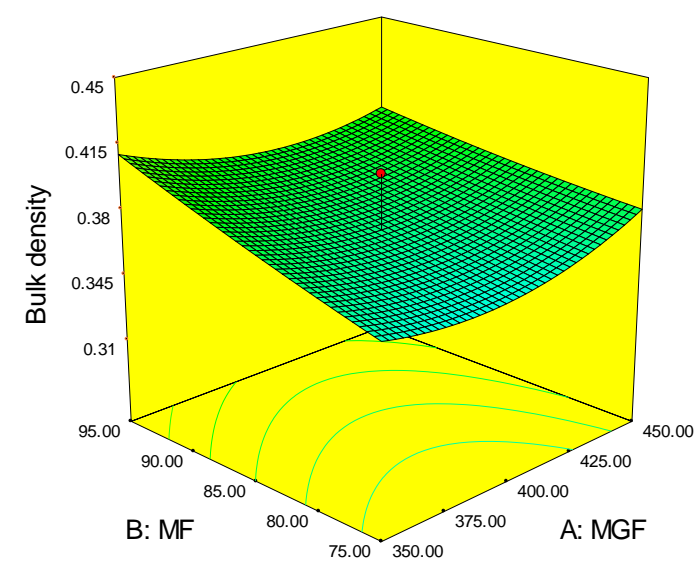


Fig.2 3D surface plot for the effect of water and JP on bulk density of jaggery based cold extruded products

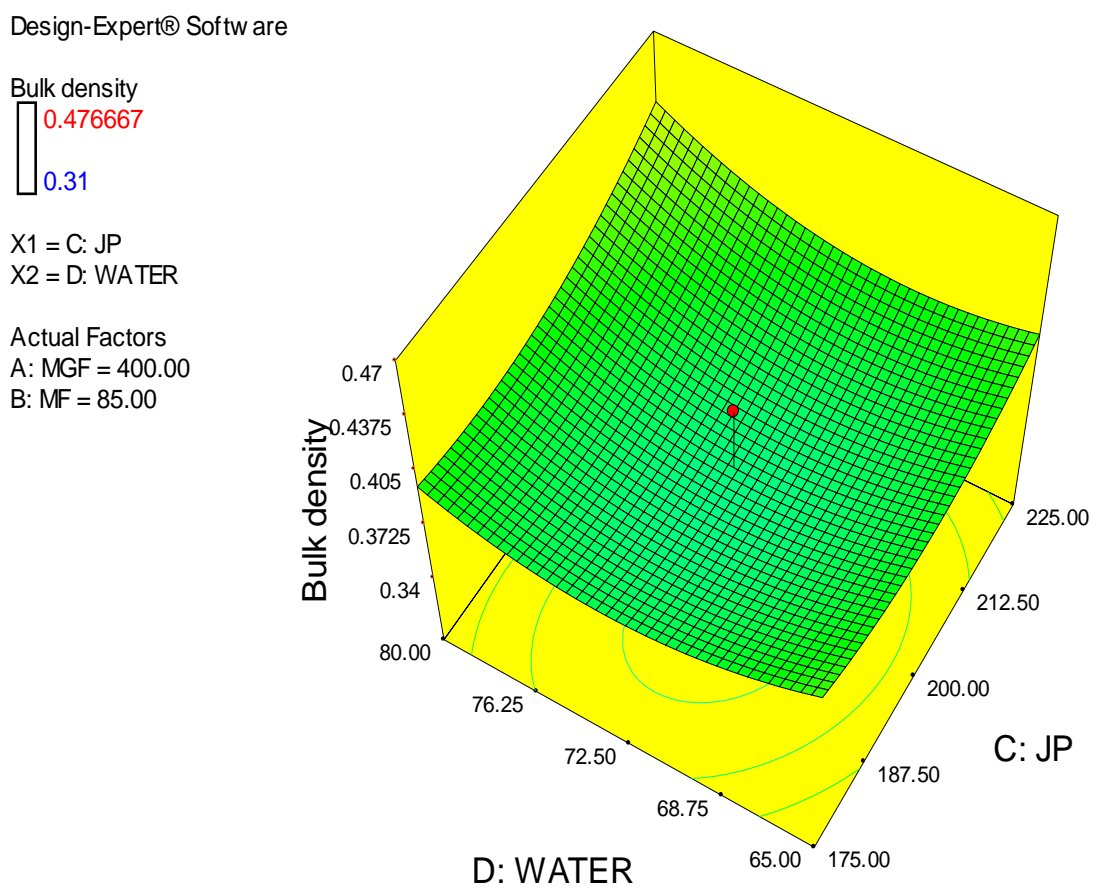

Fig.3 3D surface plot for the effect of JP and MF on bulk density of jaggery based cold extruded products

Design-Expert® Softw are
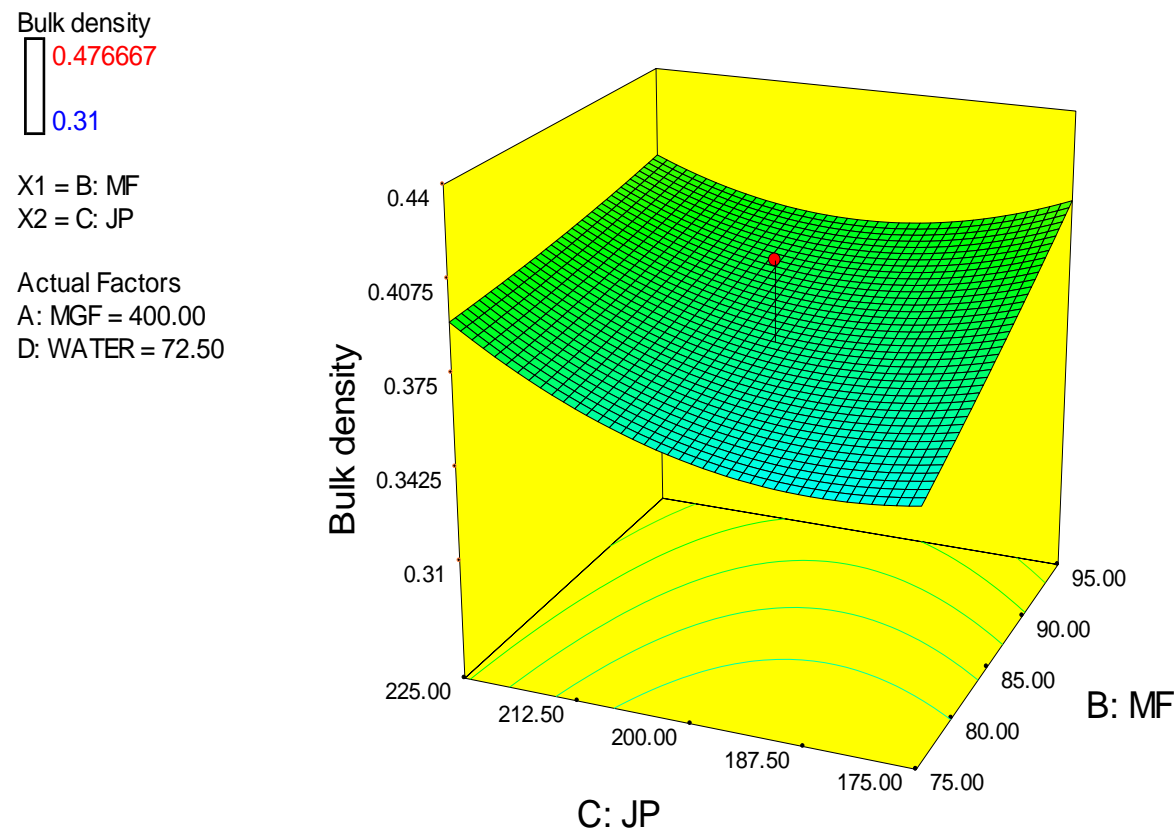
Fig.4 3D surface plot for the effect of MF and MGF on hardness of jaggery based cold extruded products

Design-Expert® Softw are

Hardness
$\begin{aligned} & \prod_{3871.03}^{14534.5} \\ & \text { X1 = A: MGF } \\ & \text { X2 = B: MF } \\ & \text { Actual Factors } \\ & \text { C: JP }=200.00 \\ & \text { D: WATER }=72.50\end{aligned}$

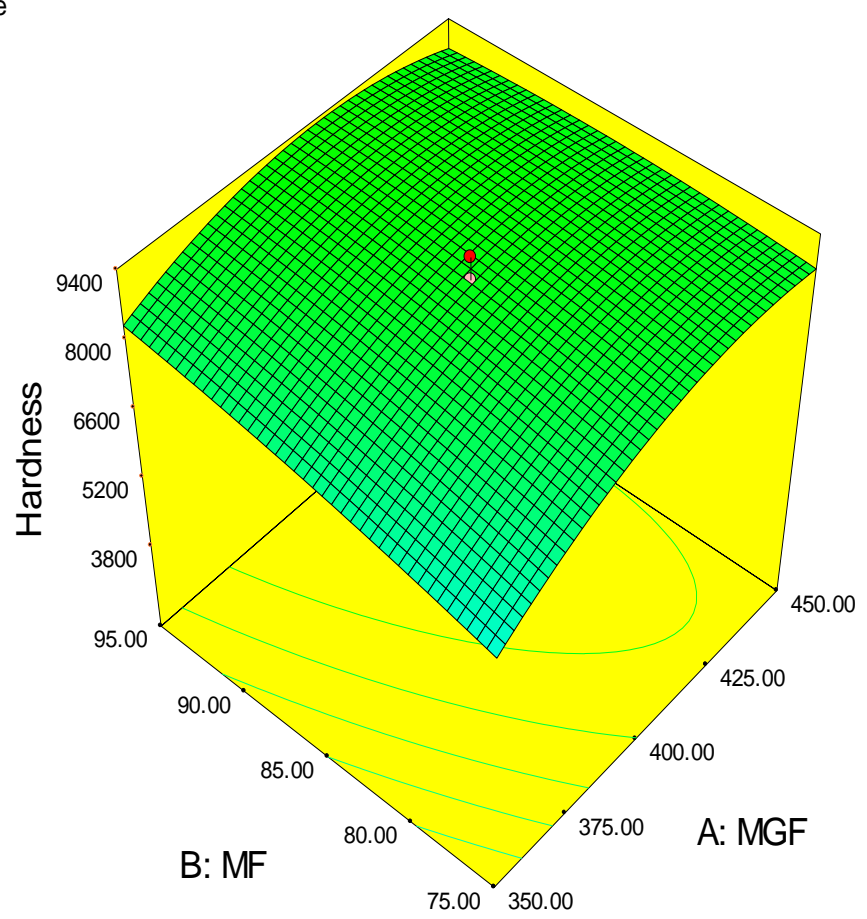

Fig.5 3D surface plot for the effect of JP and MGF on hardness of jaggery based cold extruded products

Design-Expert@ Softw are

Hardness
$\prod_{3871.03}^{14534.5}$

$X 1=A:$ MGF

$\mathrm{X} 2=\mathrm{C}: \mathrm{JP}$

Actual Factors

B: $\mathrm{MF}=85.00$

D: WATER $=72.50$

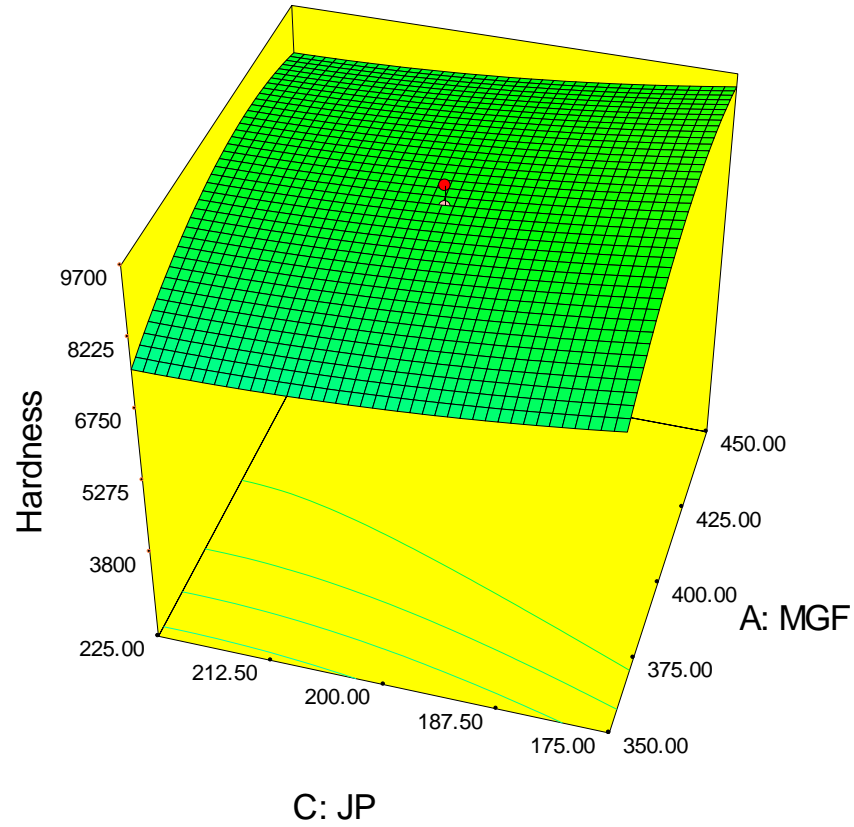


Fig.6 3D surface plot for the effect of Water and MF on hardness of jaggery based cold extruded products

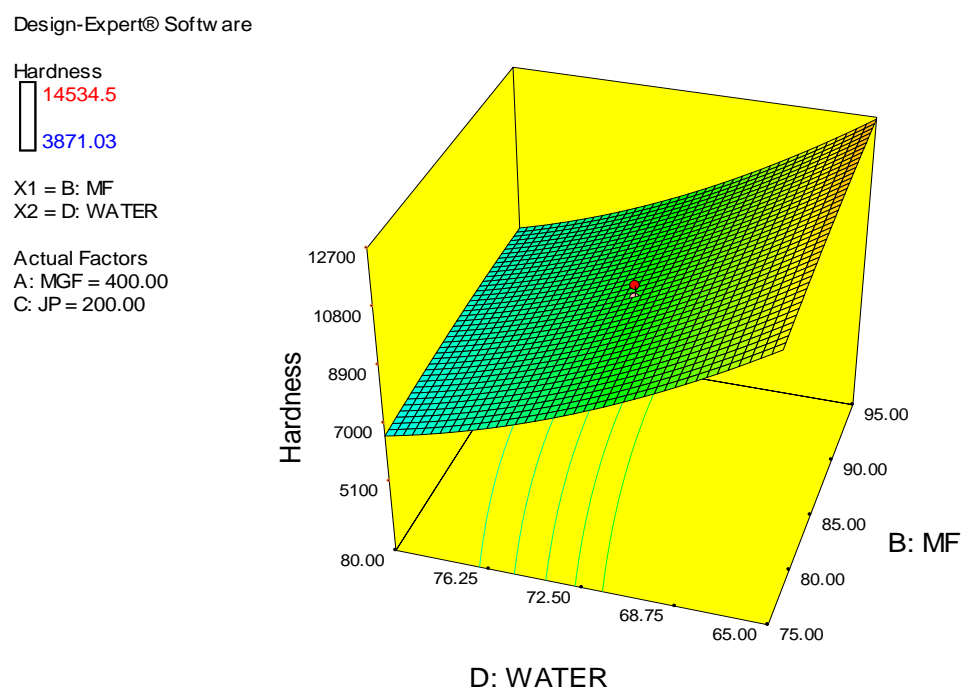

Values of "Prob > F" less than 0.0500 indicate model terms were significant. In this case $A$, $\mathrm{B}, \mathrm{C}, \mathrm{D}, \mathrm{AB}, \mathrm{AC}, \mathrm{AD}, \mathrm{BC}, \mathrm{BD}, \mathrm{CD}$ were significant model terms. Values greater than 0.1000 indicate the model terms were not significant.

\section{Analysis of response surfaces}

The Figure 1 shows that the bulk density of the jaggery based cold extruded products was decreased by decreasing the amount of maida flour and it was also decreased as the amount of multi grain flour decreases.

The Figure 2 show that the bulk density of the jaggery based cold extruded samples was first decreased by decreasing the amount of water and then it was increased. As the jaggery powder was increased, the bulk density was also increased.

The Figure 3 shows that the simultaneous increase in jaggery powder and maida flour caused increase in bulk density of the jaggery based cold extruded products. Hence, the bulk density had a positive effect with both jaggery powder and multi grain flour.
The Figure 4 shows that the hardness of the jaggery based cold extruded products was decreased with simultaneous decrease in maida flour and multi grain flour. Thus, it was observed that hardness had a positive effect with the maida flour and multi grain flour.

The Figure 5 shows that the hardness of the jaggery based cold extruded products was decreased with decreasing multi grain flour, but it was slightly increased with decreasing jaggery powder. Hence, it is noted that hardness had a positive effect with multi grain flour and had a negative effect with jaggery powder.

The Figure 6 shows that the hardness of the jaggery based cold extruded products was increased with decreasing water and was decreased with decreasing maida flour. Hence, the hardness had positive effect with maida flour and negative effect with the amount of water.

\section{Numerical optimization}

Numerical optimization technique of the Design-Expert version 8.06 software was 
used for simultaneous optimization of the multiple responses. The desired goals for each factor and response were chosen. The goals may apply to either factors or responses. The possible goals are: maximize, minimize, target, within range, none (for responses only). The independent factors viz. MGF was kept in range, JP was kept targeted and MF and Water were kept equal to while the responses viz. Bulk density was kept maximized and hardness was kept minimized. The numerical optimization results showed that the overall optimum area was predicted to be obtained by the combination of $450 \mathrm{~g}$ of MGF, $95 \mathrm{~g}$ of MF, $225 \mathrm{~g}$ of JP and $80 \mathrm{ml}$ of Water i.e., R17 (MGF-450 g, MF-95 g, JP$225 \mathrm{~g}$, Water-80 ml) with desirability of 0.875 $\%$ by response surface plots and response optimizer.

Jaggery is a traditional unrefined noncentrifugal sugar consumed in Asia, Africa, Latin America and the Caribbean. India is the largest producer and consumer of jaggery. Out of total world production, more than $70 \%$ is produced in India. It is consumed in almost all sections of the society as a sweetener, and as a source of energy. It is also used in animal feed mixtures. Jaggery is among major agro processing industries in India. Value addition to solid jaggery by inclusion of nutritive substances through puffed rice, gram, sesame and various kinds of nuts (cashew, almond), vitamins, iron, and taste enhancers like chocolate powder will increase demand for this kind of jaggery.

The bulk density of jaggery based cold extruded products was ranged from 0.31 to $0.47 \mathrm{~g} / \mathrm{cc}$. The lowest bulk density was found for R29 (MGF-400 g, MF-65 g, JP- $200 \mathrm{~g}$, Water-72.5 ml) and the highest run was found for R25 (MGF-350 g, MF-75 g, JP- $225 \mathrm{~g}$, Water-80 $\mathrm{ml}$ ). The hardness of the uncooked jaggery based cold extruded products was ranged from 3871.026 to $14534.503 \mathrm{~N}$. The numerical optimization showed that R17 (MGF-450 g, MF-95 g, JP- 225 g, Water-80 $\mathrm{ml}$ ) sample was selected as best sample with desirability of 0.875 .

\section{References}

Deepika Balfour, Chitra Sonkar and Shakti Sharma. 2014. Development and Quality Evaluation of Extruded Fortified Corn Snack. International Journal of Food and Nutritional Sciences, Vol.3, Iss.4

Devaraju, B., 2003. Development of pasta products based on finger millet composite flour. M.Sc. Thesis, University of Agricultural Sciences, Bangalore.

Gabriel Ifeanyi Okafor and Faith Chinenye Ugwu. 2014. Production and evaluation of cold extruded and baked ready-to-eat snacks from blends of breadfruit (Treculia africana), cashewnut (Anacardium occidentale) and coconut (Cocos nucifera. Food Science and Quality Management, Vol. 23.

Jagannadha Rao PVK, Madhuswetha Das and Das SK. 2007. Jaggery - a traditional Indian sweeter. Indian journal of traditional knowledge 6(1): 95-102.

Jagannadha Rao PVK, Sridevi P, Jha SN, Veerabhadra Rao K, Venugopala Rao. 2015. Jaggery Research in India. AICRP on Post-Harvest Technolgy, Regional Agricultural Research Station, Anakapalle, Pg. 78-80, 82-83.

Jeffrey A Gwirtz and Maria Nieves GarciaCasal. 2014. Processing maize flour and corn meal food products. Annals of the New York Academy Science, 1312(1): 66-75

Khan Chand, Anupama Singh and Shahi NC. 2012. Engineering properties of extruded jaggery based snack from soywheat flour. Environment and Ecology 30 (2): 299-302. 
Khulve Prateek, Aditya Paliwal and Shubham Doval. 2016. Development of jaggery based energy bar and its sensory evaluation. International Conference on Recent Advances in Agriculture, Food Science, Forestry, Horticulture, Aquaculture, Animal Sciences, Biodiversity, Environmental Engineering and Climate Change. ISBN-978-93-85822-22-3.

Nath A, Dutta D, Pawan Kumar and Singh JP. 2015. Review on recent advances in value addition of jaggery based products. Journal of Food Processing and Technology, Vol.6, Iss.4.

Prabal Pratap Singh and Sumanth Pratap Singh. 2014. Nutritional importance of jaggery in human diet, Souvenir cum proceedings of national meet on modernization of jaggery industry in India, Lucknow, pp 119-120.

Prashant PS and Rama Chandra Pradhan. 2013. Preservation and value addition of jaggery. International Journal of Agricultural Engineering, Vol.6, Iss.2.

Ranganna B, Ramya KG, Kalpana B and Veena R. 2014. Development of cold extruded products (Vermicelli and Pasta). International Journal of Agricultural Engineering Vol. 7 Iss. 2.

Seema B.R, Sudheer K.P., Ranasalva N, Vimithat, and Sankalpa K.B. 2016. Effect of Storage on Cooking Qualities of Millet Fortified Pasta Products. Advances in Life Sciences 5(17), 66586662

Sudha Devi G. 2012. Development of extruded products from small millets. Unpublished thesis. Department of Agricultural Engineering, University of Agricultural Sciences, Bangalore.

Sumathi A., Ushakumari R., Malleshi N.G. 2007. Physicochemical characteristics, nutritional quality and shelf - life of pearl millet based extrusion cooked supplementary foods. International Journal of Food Science and Nutrition, $58(5), 350-362$.

Thilagavathi T, Kanchana S, Banumathi P and Ilamaran M. 2015. Standardization of extruded products using modified millet flour and pulse flour. International Journal of Food and Nutritional Sciences, Vol.4, Iss.4.

\section{How to cite this article:}

Pravallika, B., S. Patel, P.V.K. Jagannadha Rao and Sreedevi, P. 2018. Development and Optimization of Jaggery Based Cold Extruded Products. Int.J.Curr.Microbiol.App.Sci. 7(09): 2950-2962. doi: https://doi.org/10.20546/ijcmas.2018.709.367 